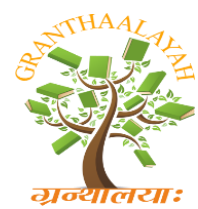

INTERNATIONAL JOURNAL OF RESEARCH GRANTHAALAYAH

A knowledge Repository

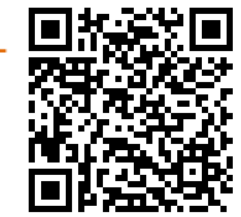

Management

\title{
AVIATION SAFETY CULTURE MEASUREMENT MODEL FIT VALIDATION OF A SURVEY FOR THE AVIATION MAINTENANCE REPAIR ORGANIZATIONS
}

\author{
Vahap ÖNEN ${ }^{* 1}$ \\ ${ }^{* 1}$ Associate Professor, OKAN University Civil Aviaition Transportation Management, \\ TURKEY
}

\begin{abstract}
It is believed that safety is the major issue for the aviation industry. According to Boeing Study $\% 15$ of the fatal accidents are incurred by maintenance sources related. On the other hand, from the last ten years safety management system which firstly introduced by ICAO became popular in the aviation industry. In the beginning, enforcement by ICAO Annex 19 then following it consequtively by EASA's regulation, at the same time issued many advisory circulars by FAA that SMS entried in force and still other authorities are acting by similar way. However, the most important element of the SMS is based on properly establishment of safety culture in organization. Up to now there are many methods introduced in the literature for measuring safety culture of aviation organizations. Even though an aviation company may select one model as to another one for measuring own safety culture, but they are not sure whether this model run perfectly and reflect true results or not. In this study it is aimed to bring out how the proposed ECAST's safety culture model which is compliance for the aviation maintenance organizations by validating Structural Equation Modelling.
\end{abstract}

Keywords:

Structural Equation Model, Safety Culture, Aviation, Maintenance, Certifying Staff.

Cite This Article: Vahap ÖNEN, "AVIATION SAFETY CULTURE MEASUREMENT MODEL FIT VALIDATION OF A SURVEY FOR THE AVIATION MAINTENANCE REPAIR ORGANIZATIONS" International Journal of Research - Granthaalayah, Vol. 4, No. 3 (2016): 59-79.

\section{INTRODUCTION}

\subsection{SAFETY CULTURE DEFINITION IN AVIATION}

Safety culture is a term that nearly everyone uses but few can agree upon its precise meaning or how it can be measured. The social as a first it comprises the beliefs, attitudes and values often unspoken of an organization's membership regarding the pursuit of safety and the second is more concrete and embraces the structures, practices, controls and policies that organizations 
possesses and employs to achieve greater safety (J.Reason, A.Hobbs 2003). A Safety Culture refers to the extent to which every individual and every group of the organization is aware of the risks and unknown hazards induced by its activities; is continuously behaving so as to preserve and enhance safety; is willing and able to adapt itself when facing safety issues; is willing to communicate safety issues; and consistently evaluates safety related behaviour (P. Montijn, B.NLR, 2009)

\subsubsection{SAFETY CULTURE REQUIREMENTS FOR AVIATION}

When it comes to review the Space Shuttle accident's executive report in 2003, it will be seen that the organizational causes of this accident are rooted in the Space Shuttle Program's history and culture. Additionally, cultural traits and organizational practices detrimental to safety were allowed to develop (Patrick Hudson, 2007). it may be cited as an examples (IAEA, 2014) because of national culture which is sub-components of the safety culture caused five serious aviation accidents that are Tenerif - Runway Incursion - Canary Island, Sprain - 1977 (583 dead), Avianca 052 - Crash - New York - 1990 (73 dead), Korean Air 801 - Crash - Guam 1997 (228 dead), The Überlingen mid-air collision - Switzerland - 2002 (71 dead), Asiana 214 Crash - San Francisco -2013 (3 dead). These samples can be risen however, nowadays it is considered that safety culture still is the most important problem in order to set up safety management system (Ender Gerede, 2012). Since safety culture is almost the root cause of the errors which are occurred by based on general system (James Reason, 2013, 81).

\subsection{AVIATION SAFETY CULTURE MODELS}

There are many kind of model for measurement and assessment of the Aviation Safety Culture in the literature. Reason Model, Hudson Model, ICAO's proposition, Cooper ve Zohar Models, Weigman \& Gibbons's SCIMS Model, Schein Model, 4P-4C Model, Cooper's interactive safety culture model may be some examples of them. One of the well-known European Aviation Safety Agency's (EASA) proposed safety culture model which is introduced by ECAST (European Commercial Aviation Safety Team) that the scope of work in this study.

\subsubsection{ECAST (EUROPEAN COMMERCIAL AVIATION SAFETY TEAM) SAFETY CULTURE MODEL}

As Safety Culture is still an emerging issue and since the introduction of the ICAO and EASA Safety Management requirements will expedite Safety Culture activity across Europe. (Piers, Montijn \& Balk, NLR 2009, Safety Culture Frame Work for the ECAST-Working Group).

Nevertheless, a strong Safety Culture is generally considered as a vital condition to a wellfunctioning of SMS. For this reason, the SMS Working Group of ECAST has been tasked to propose Safety Culture reference material.

\subsubsection{ECAST'S PROPOSED SAFETY CULTURE FRAMEWORK}

From the review of the main existing and emerging Safety Culture frameworks in aviation and beyond, we know that Safety Culture is a multi-dimensional construct. To capture the common 
and key-elements of the various leading framework, six dimensions are needed. The six Characteristics are commitment, behaviour, awareness, adaptability, information and justness. ECAST selected this model as based on Westrum's studies. Besides, there are also many others studies which indicate different characteristics for measuring safety culture. For example; Thaden, Sharma, \& Mitchell (2002) and Wiegmann et al. (2002) reviewed the safety culture literature across a number of industries and identified five critical indicators of an organization's safety culture organizational, managerial involvement, employee empowerment, accountability system, reporting system. This model had been supported by FAA (Wiegmann, D.A., von Thaden, T. L., Mitchell, A.A., Sharma, G., \& Zhang, H., 2003). When we closely looked in these six characteristics they will be represented by some indicators which are shown below:

Table 1: Safety Culture Indicators

\begin{tabular}{|l|l|}
\hline Characteristic & Indicators \\
\hline Commitment & - Management concern \\
& - Perception of importance of safety \\
& - Prioritization of safety \\
& - Safety procedures and requirements \\
& - Personal involvement and responsibility for \\
safety
\end{tabular}

\subsubsection{SAFETY CULTURE MATURITY LEVELS}

Parcker, Lawrie \& Hudson (2006) have developed a framework for development and maturation of organization Safety Culture. The framework is based on Westrum's classification of culture based on how safety-related information is handled (Westrum, R., 1992, 288-99). Westrum levels of culture are pathological, bureaucratic and generative each shortly described by Parker et al. built on this (Parker D. Lawrie, M. \& Hudson, 2006). But use five levels as Safety Culture Maturity are cited by Patric Hudson and even though it was not particularly developed for aviation industry, ECAST placed it in this framework that is indicated following figure 1. 


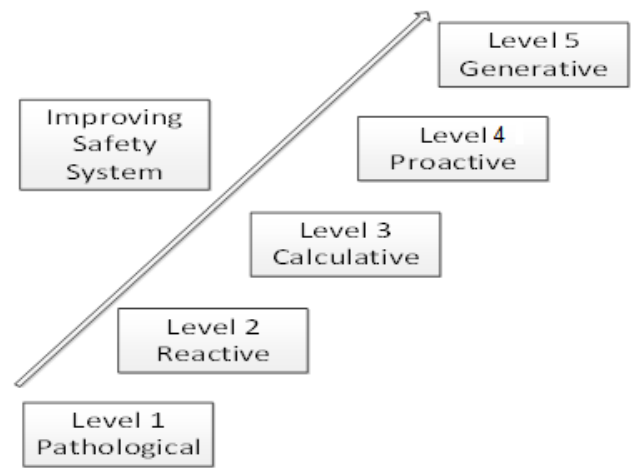

Figure 1: Safety Culture Maturity Levels according to Hudson

Another outstanding safety maturity model had been developed by also Fleming (Fleming Mark, 2000, 2000/49). The safety culture maturity of an organisation consists of ten elements, which are described as management commitment and visibility, communication, productivity versus safety, learning organisation, safety resources, participation, shared perceptions about safety, trust, industrial relations and job satisfaction and training. This model has been adapted from the safety culture components listed by the HSE in HSG487 (HSE, 1999).

\section{MATERIALS AND METHODS}

\subsection{ECAST'S SAFETY CULTURE MODEL VALIDATION FOR MAINTENANCE REPAIR ORGANIZATIONS}

\subsubsection{RESEARCH METHODOLOGY}

It is aimed by this application to determine whether or not ECAST's proposed Safety Culture Model is suitable to measure the safety culture levels of certifying staff, mechanics, noncertifying staff and whole group in a maintenance repair organization via statically model validation analysis.

\subsubsection{RESEARCH TECHNIQUE AND CONSTRAINTS}

A survey method developed in six dimensions and having a Likert type scale of 5 by EASA Safety Management Group by using Reason method and taking ICAO criteria into consideration. The research is conducted in Maintenance Repair Organization located at Turkey by using survey method on Certifying Staff, Mechanics and Non Certifying Staff, which are representing the majority of company production staff.

\subsubsection{MAIN POPULATION AND SAMPLE SIZE}

The research is conducted in the scope of Approved Maintenance Organization's Certifying Staff, Mechanics and Non Certifying Staff who are working in FAA (Federal Aviation Administration) EASA and TDGCA (Turkish Directorate General Civil Aviation). Population is formed as to include the whole of Certifying Staff and at $95 \%$ of confidence interval on Non 
Certifying Staff and Mechanics having at least 1 year experience by simple random sampling method through quota sampling (Saunders, Lewis, Thornhill, 2000).

Relevant numeric values are illustrated in the table below:

Table 2: The number of the enquetee

\begin{tabular}{|l|l|l|l|l|}
\hline Groups & $\begin{array}{l}\text { Main Population } \\
\text { (Facility 1+Facility 2) }\end{array}$ & Interviewed & $\begin{array}{l}\text { Sample Size } \\
\text { (Facility 1) }\end{array}$ & $\begin{array}{l}\text { Sample Size } \\
\text { (Facility 2) }\end{array}$ \\
\hline Certifying Staff & 120 & 110 & 60 & 50 \\
\hline Mechanics & 139 & 92 & 43 & 49 \\
\hline Non-Certifying Staff & 405 & 220 & 148 & 72 \\
\hline
\end{tabular}

\subsubsection{DATA COLLECTION}

The questionnaire is tested before the using in the field via pilot study on each group's representative sampling. At the two locations, each group who are certifying staff, mechanics and non- certifying staff are invited to the classroom in different days. First of all, they are informed respectively about to survey. Then, the representative of each group who are 25 staff fill in questionnaires since it has been translated from English to Turkish language. Thereby, 52 survey questions are checked whether they are understood by each group correctly or not. On the other hand, the purpose of time study is to determine average response time of one question because of the survey is containing 52 questions. Questionnaires are distributed to all attendances and collected back after they are filled by company safety officers. Filling the questionnaire process is conducted under the supervision of safety officers. Therefore, misunderstood questions, response time etc. have been corrected. After then, in accordance with sampling model, representative of each group member respectively are invited to the classroom for filling the questionnaire in different days at two locations (facility-1 and facility-2). Finally, the concerned survey has been conducted within two months.

\subsubsection{DESIGNING SURVEY QUESTIONNAIRE}

Questionnaire form which designed by EASA Safety Steering Group, scaled by 6 dimensions and consists in 52 questions for using aviation safety culture levels measurement. The responses are addressed on a 5 point Likert type scale ranging from 1 to 5 ( $1=$ Totally Agree, $5=$ totally disagree). This questionnaire used by translation of this scale.

\subsubsection{ANALYSIS METHODOLOGY}

The data analysed by means of SPSS and AMOS statistic software. The collected data processed by outlier analysis, homogeneity analysis for each group then exploratory factor analysis, reliability analysis are performed for each dimension of the scale by using SPSS. Thereby, uncorrelated and insignificant questions were extracted from its concerned dimension. To continue with that by means of structural equation model of the AMOS software, first order conformity factor analysis performed for the model goodness fit and validation of scale's dimensions. Finally, by the path analysis method the concerned scale was tested for each group whether they are significant to explain and aligned in response to the proposed model or not. 


\section{RESULTS AND DISCUSSIONS}

\subsection{THE PROPOSED RESEARCH MODEL}

As It can be seen that Safety Culture Model scale' consist in 6 dimensions. The model has been shown as below:

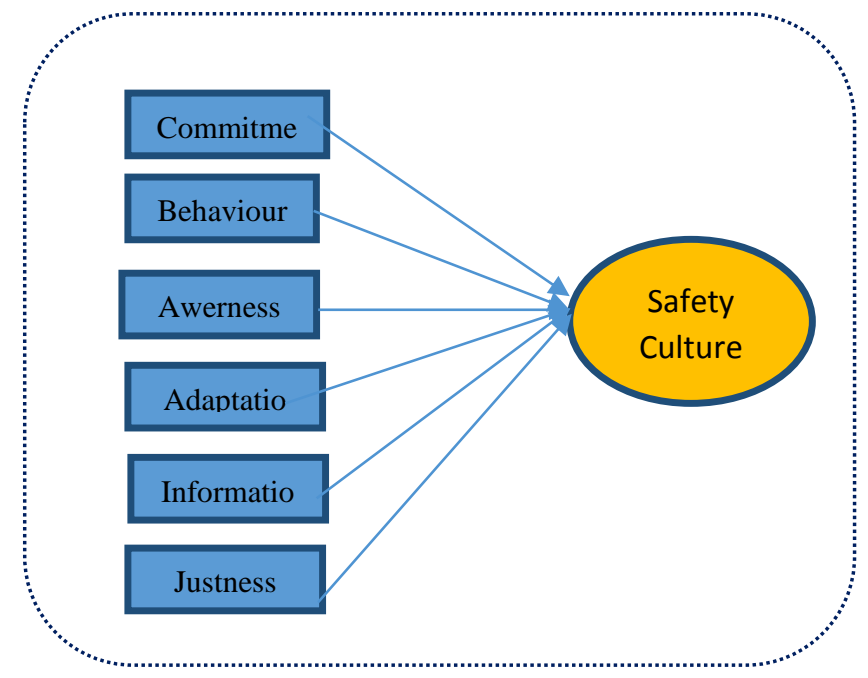

Figure 2: ECAST's Safety Culture Measurement Model in Aviation

In this study, safety culture maturity levels measured not only certifying staff but also mechanics and non-certifying group. Thereby, total company safety culture is depend on the each group safety culture which are presented as following figure.

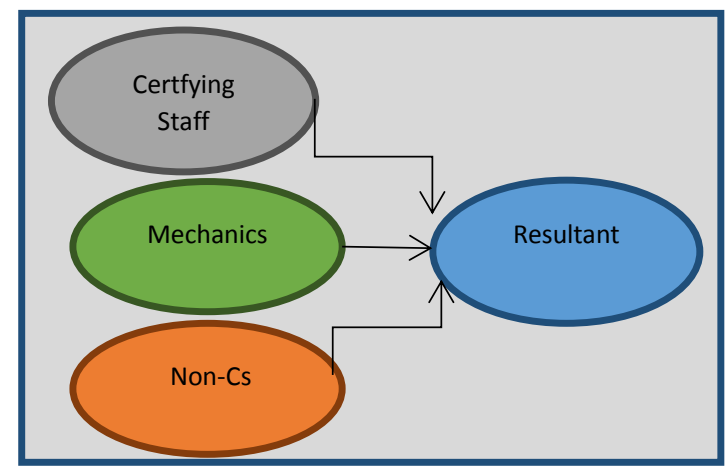

Figure 3: Each group effect on cooperate safety culture

\subsubsection{NORMALITY TESTS}

According to the Kolgmogrov-Smirnov Normality Test which run for whole group, since variable of the safety culture Sig.value >0.005 then H0 hypothesis accepted and data are distributed normally. 


\subsubsection{OUTLIERS ANALYSIS}

According to the certifying staff's outlier analysing results, the number of data 7,45,61 and 107 th accepted as outliers then they were omitted from the data list.

\subsubsection{HOMOGENEITY TEST}

According to the results of homogeneity test for the certifying staff, Sig. values $>0.05$ thereby homogeneity is validated.

\subsubsection{FACTOR ANALYSIS AND RELIABILITY ANALYSIS}

For each dimension factor analysis performed at the first step and then reliability analysis performed at the second step after uncorrelated and insignificant questions extracted from the its dimension. In order to examine reliability of structure which formed by each latent variable reliability of structure, the proportion total variance explained and Cronbach's alpha reliability criteria are calculated. Nunnalyy argue that each of structure Cronbah's alpha value must be greater than 0.70 in social sciences for reliability of measurement tool (Nunnaly, J.C. and Bernstein, I.H., 1994). Some authors suggest Measure of Sampling Adequacy which developed by Kaiser to apply the factor analysis model successfully (Rencher A.C, 1998). Hair and Et are considered to be sufficient coefficient value for reliability of structure must be greater than 0.70 and the proportion of total explained variance values must be greater than 0,50 for the latent variables (Hair, 1998). The following table indicates final results for each dimension of the Certifying Staff.

Table 3: Factor and Reliability Analysis Summary Results

\begin{tabular}{|c|c|c|c|c|c|}
\hline \multirow{2}{*}{$\begin{array}{l}\text { Certifying } \\
\text { Staff }\end{array}$} & \multirow{2}{*}{$\begin{array}{l}\text { Reliability } \\
\text { Analysis Results } \\
\text { Cronbach alpha }\end{array}$} & \multicolumn{3}{|c|}{ Exploratory Factor Analysis Results } & \multirow{2}{*}{$\begin{array}{l}\text { Extracted Questions } \\
\text { After the Factor \& } \\
\text { Reliability Analysis }\end{array}$} \\
\hline & & KMO & $\begin{array}{l}\text { Barlett } \\
\text { Sig } \\
\end{array}$ & $\begin{array}{l}\text { Total } \\
\text { Explained }\end{array}$ & \\
\hline Commitment & 0,81 & 0,81 & 0,00 & 51,79 & $1,5,7,8$ \\
\hline Behaviour & 0,74 & 0,76 & 0,00 & 50,15 & $14,17,18$ \\
\hline Awareness & 0,68 & 0,59 & 0,00 & 49,56 & 21,22 \\
\hline Adaptation & 0,70 & 0,72 & 0,00 & 40,45 & - \\
\hline Information & 0,88 & 0,84 & 0,00 & 46,7 & $31,32,33,40,41,43,44,45,47$ \\
\hline Justness & 0,74 & 0,67 & 0,00 & 56,89 & - \\
\hline
\end{tabular}

Analysis results shows that KMO values are acceptable levels, p-value for the Bartlett test is 0,00 hence, the results obtained in terms of applicability factor analysis, the data statistically is sufficient. According to the Scherer, Wiebe, Luther and Adams, if total variance explained value is between on \%40 and \%52 it is acceptable in the social science (Tavşancil, 2005, 399). Tebachnic and Fidel assert that decision of the size of the factor loadings which are acceptable should be given by researchers (Tebachnic and Fidel, 2001). Therefore, the relevant scale has been ready for the analysis of the structural equation modelling.

\subsubsection{DESCRIPTIVE STATISTICS AND DEMOGRAPHICS}

Descriptive statistics for each group are as follows: 
Certifying Staff: All certifying staff (110) gender are consist of "male" and selected $78 \%$ of the group from facility-1. The department distribution of certifying staff is base maintenance $80 \%$ and component maintenance $20 \%$.

Mechanics: There are only one woman and 91 men in mechanics group. Mechanics are selected from facility-1 as $53 \%$ and facility- 2 as $47 \%$. The department distribution of mechanics is base maintenance $71 \%$ and component maintenance $29 \%$.

Non-Certifying Staff: There are 6 women and 214 men in non-certifying staff group. Noncertifying staffs are selected from facility-1 as $33 \%$ and facility-2 as $67 \%$. The department distribution of non-certifying staff is base maintenance $67 \%$ and component maintenance $33 \%$.

Descriptive statistics which are indicated mean values and standard deviation of each dimension and safety culture levels of Certifying Staff, Mechanics and Non Certifying Staff.

Table 4: CS, Non-CS, Mechanics Means of Safety Culture Levels

\begin{tabular}{|l|l|l|l|l|l|l|}
\hline $\begin{array}{l}\text { Decsriptive } \\
\text { statistics }\end{array}$ & CS & \multicolumn{2}{l|}{ Non-CS } & \multicolumn{2}{l|}{ Mechanics } \\
\hline & Mean & $\begin{array}{l}\text { Std. } \\
\text { Deviation }\end{array}$ & Mean & $\begin{array}{l}\text { Std. } \\
\text { Deviation }\end{array}$ & Mean & $\begin{array}{l}\text { Std. } \\
\text { Deviation }\end{array}$ \\
\hline Commitment & 3,5 &, 82 & 3,4 &, 80 & 3,5 &, 81 \\
\hline Behaviour & 3,1 &, 75 & 3,2 &, 75 & 3,2 &, 66 \\
\hline Awerness & 3,4 &, 69 & 3,5 &, 70 & 3,6 &, 71 \\
\hline Adaptation & 3,2 &, 67 & 3,2 &, 76 & 3,3 &, 74 \\
\hline Information & 3,1 &, 76 & 3,2 &, 71 & 3,2 &, 71 \\
\hline Justness & 3,2 &, 62 & 2,8 &, 96 & 2,7 & 1,03 \\
\hline Safety Culture & 3,2 &, 57 & 3,2 &, 64 & 3,3 &, 64 \\
\hline $\begin{array}{l}\text { Valid N (list } \\
\text { wise) }\end{array}$ & $\mathbf{1 0 4}$ & $\mathbf{1 0 4}$ & $\mathbf{2 2 0}$ & $\mathbf{2 2 0}$ & $\mathbf{9 2}$ & $\mathbf{9 2}$ \\
\hline
\end{tabular}

As it can be seen from the table while the CS and Non-CS means of safety culture level is equal which is 3.2 therefore the safety culture level of Mechanics is slightly higher than others that is

\subsubsection{CONFIRMATORY FACTOR ANALYSIS (CFA) AND STRUCTURAL EQUATION MODEL (SEM)}

Confirmatory factor analysis (CFA) is an extension of factor analysis which tests whether a set of items defines a construct (Schumacker \& Lomax, 1996). A Confirmatory Factor Analysis was conducted to validate the measurement model of each latent construct. The CFA evaluates the construct validity of the proposed model to determine whether it is intended to measure what it is supposed to measure (Kline, 1998). The CFA was performed using AMOS 22 software. Goodness of fit indices are used to determine how well the model fit the collected data. A single fit index is not enough to support the fitness of the model to a given data set (Vandenberg \& Scarpello, 1990, 75(1), 52-67). On the other hand reporting all fit indices is not recommended (Hooper, Coughlan, \& Mullen, 2008, 6(1), 53-59). The study used for fit indexes to determine the fitness of the proposed model. The first index is the chi-square statistic which tests the closeness of fit between the model examined and a perfect fit or saturated model. It indicates the goodness of fit of the model to the data (Hu \& Bentler, 1999, 6(1), 1-55). A low value of the chisquare indicates a better fit of the model to the data. However, the chi-square index is sensitive to sample size and can result in an inflated chi-square statistics. Previous researches recommended 
a ratio of chi-square to degrees of freedom of between two and three represents an acceptable fit. The second and third fit indices are the comparative fit index (CFI) and the Tucker-Lewis index (TLI). The CFI compares the hypothesized model with a null model and considered to be reasonably robust against violation of assumption. A value above 0.95 is considered good whereas a value between 0.90 and 0.95 is acceptable. The TLI is used to compare a single model or alternative models to a null model and is less sensitive to sample size. A value of more than 0.95 indicates a good fit while a value between 0.90 and 0.95 is acceptable. In addition, a value of less than 0.90 requires a restructure of the model. The fourth and fifth indices are goodness of fit index (GFI) and adjusted goodness of fit index (AGFI). Theses indices are developed by Joreskog and Sörbom. GFI has been developed alternatively to the chi-square in order to evaluate fit of model independently from sample size. Indices of GFI and AGFI changes between 0 and 1. AGFI is an arranged derivation of the GVI to estimate parameters numbers. A value above or equal 0.90 is considered good A value above or equal 0.90 is considered good and a value equal 1 is considered perfect (Hooper, Coughlan and Mullen, 2008; Kelloway, 1989; Sümer, 2000, Schumacker and Lomax, 1996). The sixth fit index is normed fit index (NFI) which is handled in the incremental fit indices. It was developed by Bentler-Bonnet. NFI function is similar to CFI, but in the NFI, it is evaluated model estimation via comparison of the value of the chi-square independency model with the model of chi-square value. Values above 0.90 or equal is considered good and a value equal 1 is considered perfect (Kelloway, 1989; Schumacker and Lomax, 1996; Sümer, 2000; Tebacknick and Fidell, 2001). The seventh fit index is the root mean square error of approximation (RMSEA) which account for model complexity. The lower the value, the less manipulation of the fit exists. A value of less than 0.05 considered a good fit while a value between 0.05 and 0.08 indicate an adequate fit. A model of 0.10 or more considered poor fit to the data (Evans et al., 2007).

\subsubsection{COMMITMENT}

The dimension of the commitment, AMOS trimmed model solution and model fit values are resulted in acceptable limits which are indicated below scheme and in table 5 for Certifying Staff.

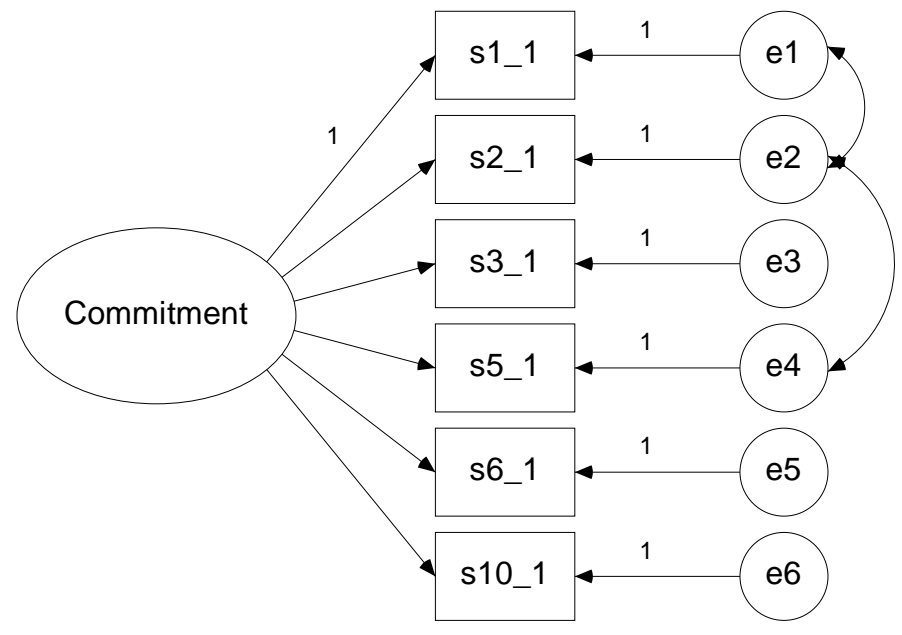

Figure 4: Trimmed Model for Organisational Commitment 
Table 5: Model fit indices for Organizational Commitment

\begin{tabular}{|l|l|l|l|l|l|l|l|}
\hline Dimensions & $\begin{array}{l}\text { CMIN/DIF } \\
\mathbf{5}\end{array}$ & $\begin{array}{l}\text { GFI } \\
\mathbf{> 0 , 8 5}\end{array}$ & $\begin{array}{l}\text { AGFI } \\
\mathbf{> 0 , 8 0}\end{array}$ & $\begin{array}{l}\text { CFI } \\
\mathbf{> 0 , 9 0}\end{array}$ & $\begin{array}{l}\text { NFI } \\
\mathbf{> 0 , 9 0}\end{array}$ & $\begin{array}{l}\text { TLI } \\
\mathbf{0 0 , 9 0}\end{array}$ & $\begin{array}{l}\text { RMSEA } \\
\mathbf{< , 0 8}\end{array}$ \\
\hline &, 889 &, 981 &, 944 & 1,000 &, 968 & 1,009 &, 000 \\
\hline
\end{tabular}

\subsubsection{BEHAVIOUR}

The dimension of the behaviour, AMOS trimmed model solution and model fit values are resulted in acceptable as seen below scheme and in table 6 for Certifying Staff.

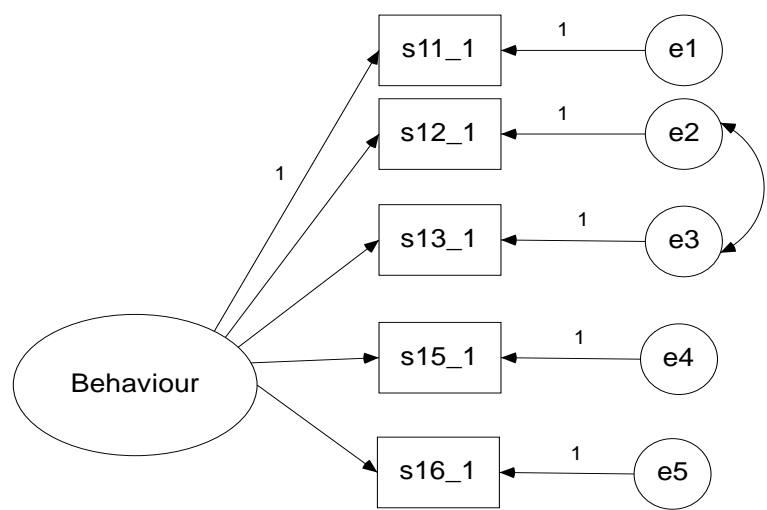

Figure 5: Trimmed Model for Organisational Behaviour

Table 6: Model fit indices for Organizational Behaviour

\begin{tabular}{|l|l|l|l|l|l|l|l|}
\hline Dimensions & $\begin{array}{l}\text { CMIN/DIF } \\
\mathbf{< 5}\end{array}$ & $\begin{array}{l}\text { GFI } \\
\mathbf{> 0 , 8 5}\end{array}$ & $\begin{array}{l}\text { AGFI } \\
\mathbf{> 0 , 8 0}\end{array}$ & $\begin{array}{l}\text { CFI } \\
\mathbf{> 0 , 9 0}\end{array}$ & $\begin{array}{l}\text { NFI } \\
\mathbf{> 0 , 9 0}\end{array}$ & $\begin{array}{l}\text { TLI } \\
\mathbf{0 0 , 9 0}\end{array}$ & $\begin{array}{l}\text { RMSEA } \\
\mathbf{< , 0 8}\end{array}$ \\
\hline & 4,154 &, 984 &, 939 &, 999 &, 964 &, 996 &, 019 \\
\hline
\end{tabular}

\subsubsection{AWARENESS}

The dimension of the awareness, AMOS trimmed model solution and model fit values are resulted in as seen below for Certifying Staff.

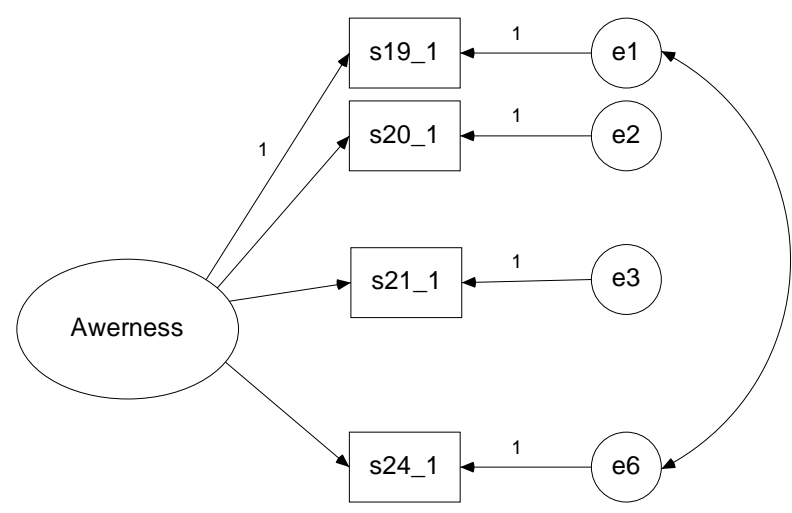

Figure 6: Trimmed Model for Organisational Awareness 
Table 7: Model fit indices for Organizational Awareness

\begin{tabular}{|l|l|l|l|l|l|l|l|}
\hline Dimensions & $\begin{array}{l}\text { CMIN/DIF } \\
\mathbf{< 5}\end{array}$ & $\begin{array}{l}\text { GFI } \\
\mathbf{7 0 , 8 5}\end{array}$ & $\begin{array}{l}\text { AGFI } \\
\mathbf{> 0 , 8 0}\end{array}$ & $\begin{array}{l}\text { CFI } \\
\mathbf{> 0 , 9 0}\end{array}$ & $\begin{array}{l}\text { NFI } \\
\mathbf{> 0 , 9 0}\end{array}$ & $\begin{array}{l}\text { TLI } \\
\mathbf{0 0 , 9 0}\end{array}$ & $\begin{array}{l}\text { RMSEA } \\
\mathbf{0 0 , 0 8}\end{array}$ \\
\hline & 1,417 &, 993 &, 932 &, 995 &, 985 & 972 &, 064 \\
\hline
\end{tabular}

\subsubsection{ADAPTATION}

The dimension of adaptation AMOS trimmed model solution and model fit values are resulted in as seen below for Certifying Staff.

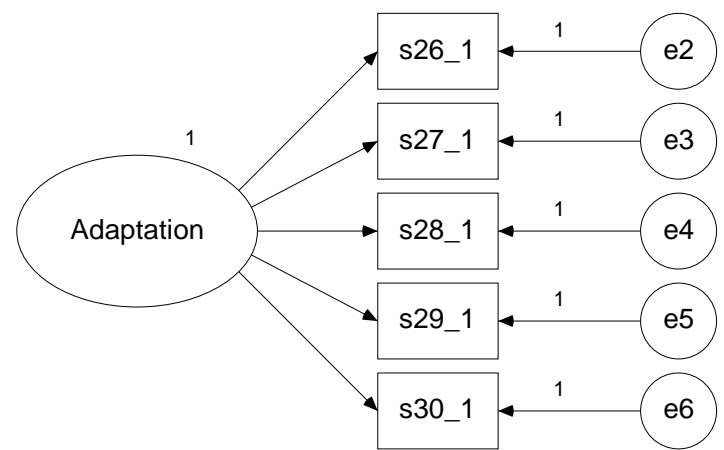

Figure 7: Trimmed Model for Organizational Adaptation

Table 8: Model fit indices for Organizational Adaptation

\begin{tabular}{|l|l|l|l|l|l|l|l|}
\hline Dimensions & $\begin{array}{l}\text { CMIN/DIF } \\
\mathbf{5 5}\end{array}$ & $\begin{array}{l}\text { GFI } \\
\mathbf{> 0 , 8 5}\end{array}$ & $\begin{array}{l}\text { AGFI } \\
\mathbf{> 0 , 8 0}\end{array}$ & $\begin{array}{l}\text { CFI } \\
\mathbf{> 0 , 9 0}\end{array}$ & $\begin{array}{l}\text { NFI } \\
\mathbf{> 0 , 9 0}\end{array}$ & $\begin{array}{l}\text { TLI } \\
\mathbf{> 0 , 9 0}\end{array}$ & $\begin{array}{l}\text { RMSEA } \\
\mathbf{< 0 , 0 8}\end{array}$ \\
\hline & 1,469 &, 973 &, 918 &, 974 &, 927 &, 948 &, 067 \\
\hline
\end{tabular}

\subsubsection{INFORMATION}

The dimension of the information, AMOS trimmed model solution and good of fitness values are resulted in as seen below for Certifying Staff.

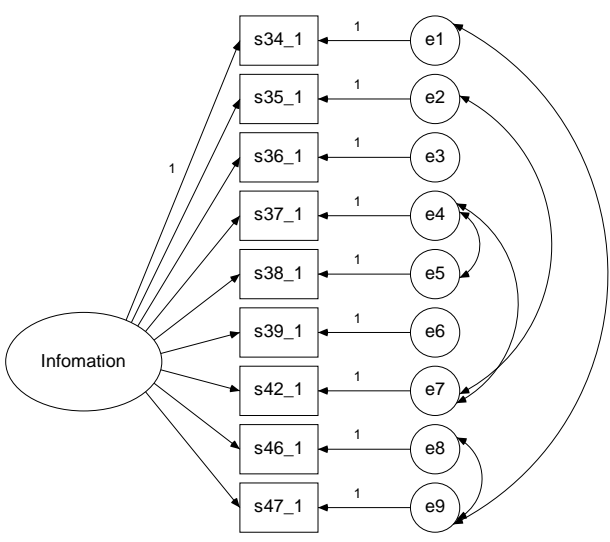

Figure 8: Trimmed Model for Organisational Information 
Table 9: Model fit indices for Organizational Information

\begin{tabular}{|l|l|l|l|l|l|l|l|}
\hline Dimensions & $\begin{array}{l}\text { CMIN/DIF } \\
\mathbf{< 5}\end{array}$ & $\begin{array}{l}\text { GFI } \\
\mathbf{> 0 , 8 5}\end{array}$ & $\begin{array}{l}\text { AGFI } \\
\mathbf{8 0 , 8 0}\end{array}$ & $\begin{array}{l}\text { CFI } \\
\mathbf{> 0 , 9 0}\end{array}$ & $\begin{array}{l}\text { NFI } \\
>0,90\end{array}$ & $\begin{array}{l}\text { TLI } \\
\mathbf{0 0 , 9 0}\end{array}$ & $\begin{array}{l}\text { RMSEA } \\
\mathbf{0 0 , 0 8}\end{array}$ \\
\hline & 1,211 &, 946 &, 890 &, 982 &, 909 &, 970 &, 045 \\
\hline
\end{tabular}

\subsubsection{JUSTNESS}

The dimension of the information, AMOS trimmed model solution and good of fitness values are resulted in as seen below for Certifying Staff.

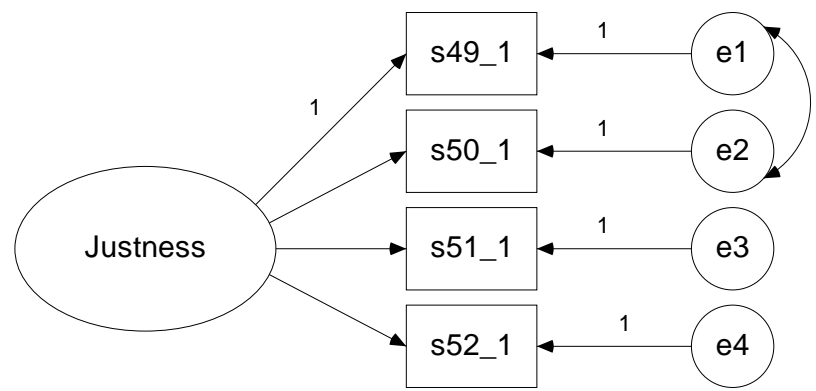

Figure 9: Trimmed Model for Organisational Justness

Table 10: Model fit indices for Organizational Justness

\begin{tabular}{|l|l|l|l|l|l|l|l|}
\hline Dimensions & $\begin{array}{l}\text { CMIN/DIF } \\
\mathbf{5}\end{array}$ & $\begin{array}{l}\text { GFI } \\
\mathbf{7 0 , 8 5}\end{array}$ & $\begin{array}{l}\text { AGFI } \\
\mathbf{> 0 , 8 0}\end{array}$ & $\begin{array}{l}\text { CFI } \\
\mathbf{> 0 , 9 0}\end{array}$ & $\begin{array}{l}\text { NFI } \\
\mathbf{> 0 , 9 0}\end{array}$ & $\begin{array}{l}\text { TLI } \\
\mathbf{0 0 , 9 0}\end{array}$ & $\begin{array}{l}\text { RMSEA } \\
\mathbf{0 0 , 0 8}\end{array}$ \\
\hline &, 176 &, 999 &, 991 & 1,000 &, 998 & 1,058 &, 000 \\
\hline
\end{tabular}

\subsection{THE FIRST ORDER CONFIRMATORY FACTOR ANALYSIS AND STRUCTURAL EQUATION MODEL}

When we performed the first order confirmatory factor analysis for Certifying Staff in all dimensions by using SEM we would be got following modified model. 


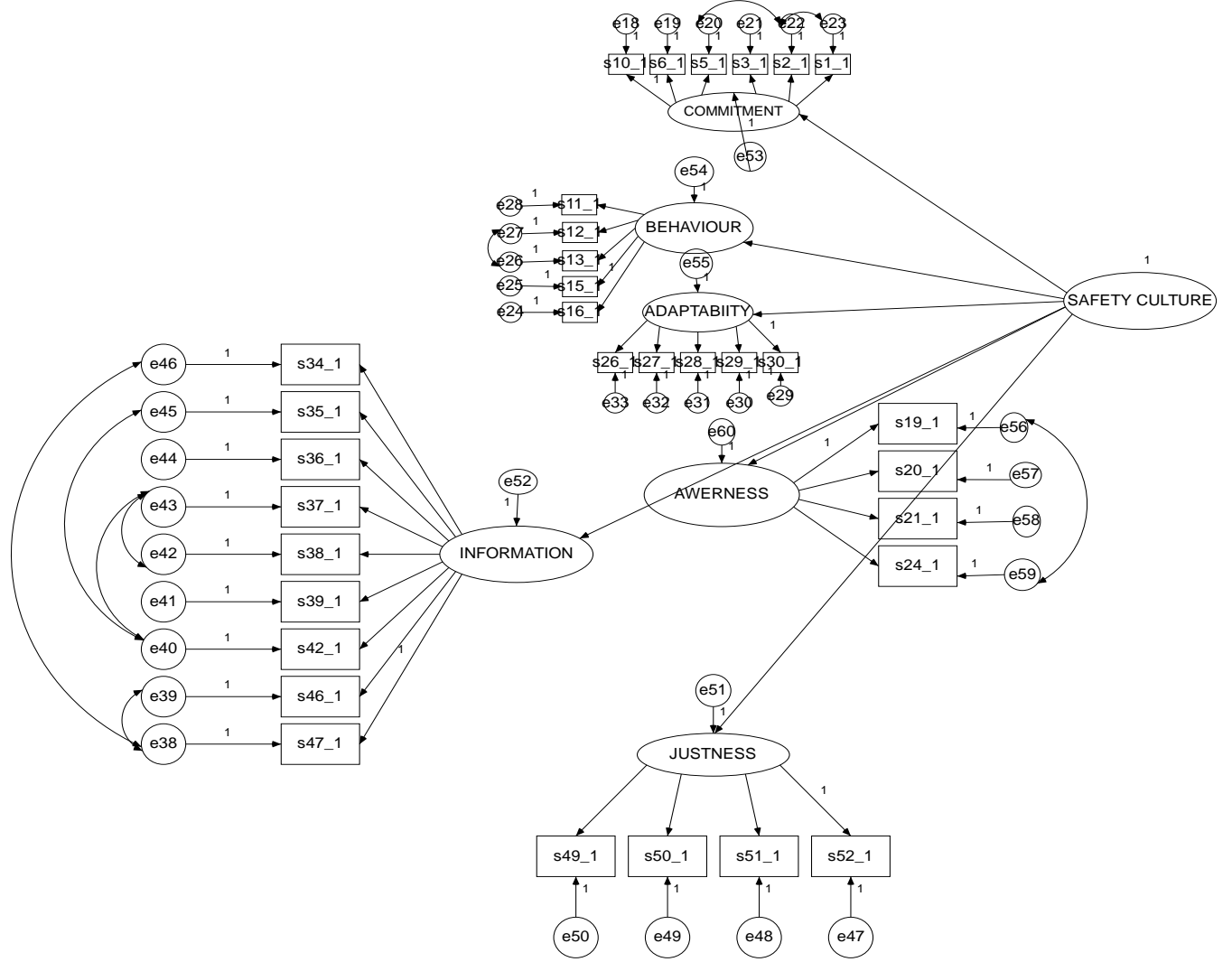

Figure 10: Confirmatory Factor Analysis and Structural Equation Model

The concerned SEM 1 regression weights and estimated values are acceptable levels and seen as follows:

Table 11: Regression Weights: (Group number 1 - Default model)

\begin{tabular}{|l|l|l|l|l|l|}
\hline & & Estimate & S.E. & C.R. & P \\
\hline COMMITMENT & SAFETY CULTURE &, 503 &, 103 & 4,875 & $* * *$ \\
\hline ADAPTABILITY & SAFETY CULTURE &, 627 &, 096 & 6,550 & $* * *$ \\
\hline BEHAVIOUR & SAFETY CULTURE &, 700 &, 103 & 6,833 & $* * *$ \\
\hline AWERENESS & SAFETY CULTURE &, 650 &, 085 & 7,686 & $* * *$ \\
\hline JUSTNESS & SAFETY CULTURE &, 661 &, 106 & 6,222 & $* * *$ \\
\hline INFORMATION & SAFETY CULTURE &, 419 &, 089 & 4,694 & $* * *$ \\
\hline s10_1 & COMMITMENT & 1,000 & & & \\
\hline s6_1 & COMMITMENT &, 932 &, 176 & 5,286 & $* * *$ \\
\hline s5_1 & COMMITMENT & 1,076 &, 204 & 5,283 & $* * *$ \\
\hline s3_1 & COMMITMENT &, 854 &, 157 & 5,441 & $* * *$ \\
\hline s2_1 & COMMITMENT &, 893 &, 166 & 5,390 & $* * *$ \\
\hline s111 & COMMITMENT &, 990 &, 190 & 5,212 & $* * *$ \\
\hline s16_1 & BEHAVIOUR & 1,000 & & & \\
\hline s15_1 & BEHAVIOUR &, 801 &, 156 & 5,141 & $* * *$ \\
\hline s13_1 & BEHAVIOUR &, 772 &, 166 & 4,651 & $* * *$ \\
\hline s12_1 & BEHAVIOUR &, 663 &, 182 & 3,640 & $* * *$ \\
\hline s11_1 & BEHAVIOUR &, 847 &, 155 & 5,450 & $* * *$ \\
\hline s30_1 & ADAPTABILITY & 1,000 & & & \\
\hline s2911 & ADAPTABILITY & 1,051 &, 197 & 5,330 & $* * *$ \\
\hline s28_1 & ADAPTABILITY &, 949 &, 158 & 6,002 & $* * *$ \\
\hline s27_1 & ADAPTABILITY &, 595 &, 135 & 4,416 & $* * *$ \\
\hline s26_1 & ADAPTABILITY &, 644 &, 158 & 4,070 & $* * *$ \\
\hline
\end{tabular}




\begin{tabular}{|l|l|l|l|l|l|}
\hline s47_1 & INFORMATION & 1,000 & & & \\
\hline s46_1 & INFORMATION &, 836 &, 184 & 4,538 & $* * *$ \\
\hline s42_1 & INFORMATION & 1,122 &, 277 & 4,052 & $* * *$ \\
\hline s39_1 & INFORMATION & 1,053 &, 264 & 3,995 & $* * *$ \\
\hline s38_1 & INFORMATION & 1,137 &, 278 & 4,086 & $* * *$ \\
\hline s37_1 & INFORMATION & 1,212 &, 282 & 4,304 & $* * *$ \\
\hline s36_1 & INFORMATION & 1,240 &, 296 & 4,187 & $* * *$ \\
\hline s35_1 & INFORMATION & 1,616 &, 350 & 4,616 & $* * *$ \\
\hline s34_1 & INFORMATION & 1,402 &, 289 & 4,847 & $* * *$ \\
\hline s52_1 & JUSTNESS & 1,000 & & & \\
\hline s51_1 & JUSTNESS & 1,110 &, 186 & 5,973 & $* * *$ \\
\hline s50_1 & JUSTNESS &, 674 &, 148 & 4,556 & $* * *$ \\
\hline s49_1 & JUSTNESS &, 628 &, 137 & 4,582 & $* * *$ \\
\hline s19_1 & AWARENESS & 1,000 & & & \\
\hline s20_1 & AWARENESS &, 851 &, 110 & 7,715 & $* *$ \\
\hline s21_1 & AWARENESS &, 621 &, 126 & 4,925 & $* * *$ \\
\hline s24_1 & AWARENESS &, 585 &, 154 & 3,811 & $* * *$ \\
\hline
\end{tabular}

Regarding model fit values are acceptable and have been calculated as below:

Table 12: Regarding model fit values

\begin{tabular}{|c|c|c|c|c|c|}
\hline CMIN Model & NPAR & CMIN & DF & $\mathrm{P}$ & CMIN/DF \\
\hline Default model & 81 & 761,940 & 480 & ,000 & 1,587 \\
\hline Saturated model & 561 & ,000 & 0 & & \\
\hline Independence model & 33 & 1854,802 & 528 & , 000 & 3,513 \\
\hline $\begin{array}{l}\text { RMR, GFI } \\
\text { Model }\end{array}$ & RMR & GFI & AGFI & PGFI & \\
\hline Default model & ,091 & ,717 & ,669 & ,613 & \\
\hline Saturated model &, 000 & 1,000 & & & \\
\hline Independence model & ,312 & ,251 & ,204 & ,236 & \\
\hline $\begin{array}{l}\text { RMSEA } \\
\text { Model } \\
\end{array}$ & RMSEA & LO 90 & HI 90 & PCLOSE & \\
\hline Default model & ,076 & ,065 &, 085 &, 000 & \\
\hline Independence model &, 156 & ,149 &, 164 &, 000 & \\
\hline $\begin{array}{l}\text { Baseline Comparisons } \\
\text { Model }\end{array}$ & $\begin{array}{l}\text { NFI } \\
\text { Delta1 }\end{array}$ & $\begin{array}{l}\text { RFI } \\
\text { rho1 }\end{array}$ & $\begin{array}{l}\text { IFI } \\
\text { Delta2 }\end{array}$ & $\begin{array}{l}\text { TLI } \\
\text { rho2 }\end{array}$ & CFI \\
\hline Default model & ,589 & ,548 & ,795 & ,766 & ,788 \\
\hline Saturated model & 1,000 & & 1,000 & & 1,000 \\
\hline Independence model &, 000 & ,000 &, 000 &, 000 &, 000 \\
\hline
\end{tabular}

\subsubsection{CERTIFYING STAFF, MECHANICS, NON- CERTIFYING STAFF PATH ANALYSIS}

Confirmatory Factor Analysis which explained above not only performed Certifying staff but also performed for the Mechanics and Non Certifying Staff. Therefore, when it comes to path analysis for each group, as specified in below, by using the latent variables the related structural equation model developed and model fit values calculated for each group. 


\subsubsection{CERTIFYING STAFF ECAST MODEL PATH ANALYSIS}

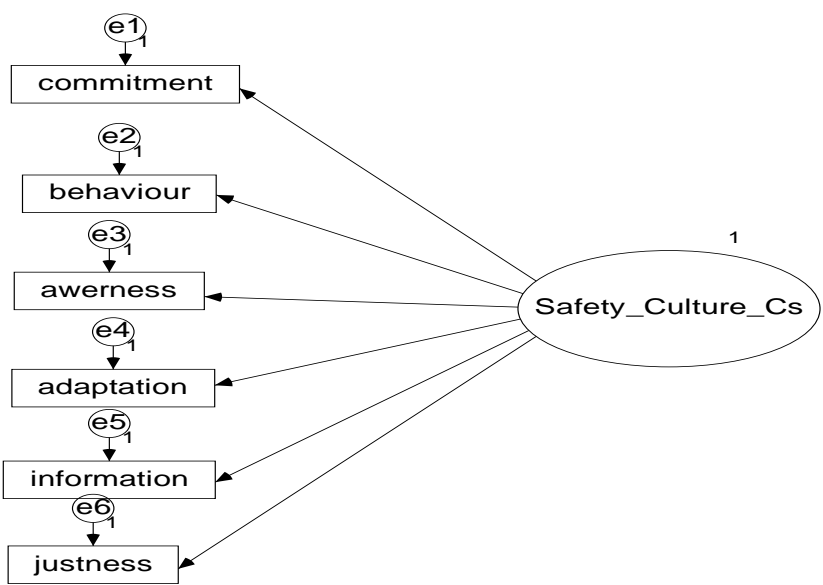

Figure 11: Certifying Staff ECAST Model Path Analysis

The concerned SEM 2 regression weights and estimated values are acceptable levels and seen as follows

Table 13: Regression Weights: (Group number 1 - Default model)

\begin{tabular}{|l|l|l|l|l|l|}
\hline & & Estimate & S.E. & C.R. & P \\
\hline Commitment & Safety_Culture_Cs &, 503 &, 077 & 6,574 & $* * *$ \\
\hline Behaviour & Safety_Culture_Cs &, 582 &, 065 & 9,003 & *** \\
\hline Awareness & Safety_Culture_Cs &, 550 &, 059 & 9,353 & $* * *$ \\
\hline Adaptation & Safety_Culture_Cs &, 516 &, 058 & 8,958 & $* * *$ \\
\hline Information & Safety_Culture_Cs &, 508 &, 051 & 9,870 & $* * *$ \\
\hline Justness & Safety_Culture_Cs &, 560 &, 067 & 8,425 & $* * *$ \\
\hline
\end{tabular}

Regarding model fit values are acceptable and have been calculated as below:

Table 14: Regarding model fit values

\begin{tabular}{|c|c|c|c|c|c|}
\hline CMIN Model & NPAR & CMIN & $\mathrm{DF}$ & $\mathrm{P}$ & CMIN/DF \\
\hline Default model & 12 & 3,797 & 9 & ,924 &, 422 \\
\hline Saturated model & 21 & ,000 & 0 & & \\
\hline Independence model & 6 & 309,088 & 15 &, 000 & 20,606 \\
\hline $\begin{array}{l}\text { RMR, GFI } \\
\text { Model }\end{array}$ & RMR & GFI & AGFI & PGFI & \\
\hline Default model & ,011 & ,988 & ,971 & ,423 & \\
\hline Saturated model &, 000 & 1,000 & & & \\
\hline Independence model & ,245 & ,380 &, 132 & ,272 & \\
\hline $\begin{array}{l}\text { RMSEA } \\
\text { Model }\end{array}$ & RMSEA & LO 90 & HI 90 & PCLOSE & \\
\hline Default model &, 000 &, 000 &, 036 & ,966 & \\
\hline Independence model &, 436 & ,395 &, 479 &, 000 & \\
\hline $\begin{array}{l}\text { Baseline Comparisons } \\
\text { Model }\end{array}$ & $\begin{array}{l}\text { NFI } \\
\text { Delta1 }\end{array}$ & $\begin{array}{l}\text { RFI } \\
\text { rho1 }\end{array}$ & $\begin{array}{l}\text { IFI } \\
\text { Delta2 }\end{array}$ & $\begin{array}{l}\text { TLI } \\
\text { rho2 }\end{array}$ & CFI \\
\hline Default model & ,988 & ,980 & 1,017 & 1,029 & 1,000 \\
\hline Saturated model & 1,000 & & 1,000 & & 1,000 \\
\hline Independence model &, 000 &, 000 &, 000 &, 000 & 000 \\
\hline
\end{tabular}




\subsubsection{NON-CERTIFYING STAFF ECAST MODEL PATH ANALYSIS}

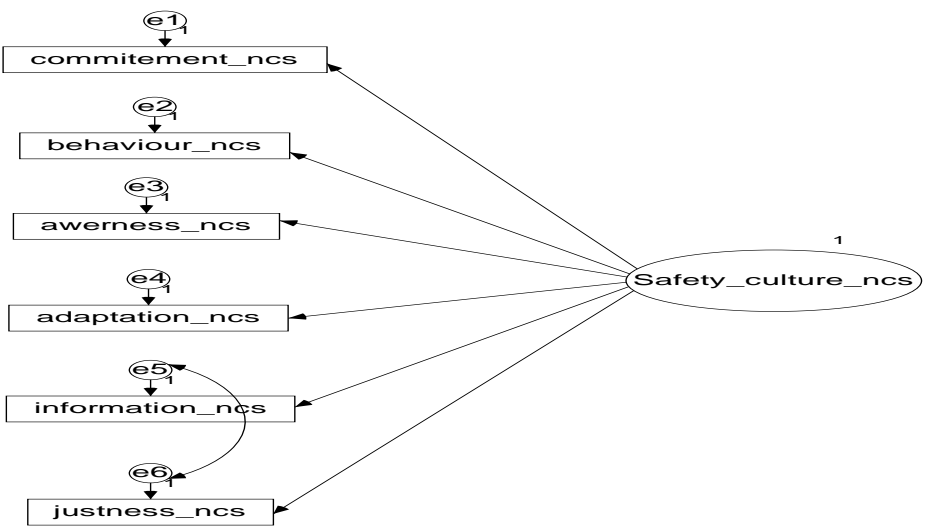

Figure 12: Non-Certifying Staff ECAST Model Path Analysis

The concerned SEM 2 regression weights and estimated values are acceptable levels and seen as follows Regression Weights: (Group number 1 - Default model)

Table 15: Regression Weights: (Group number 1 - Default model)

\begin{tabular}{|l|l|l|l|l}
\hline & & Estimate & S.E. & C.R. \\
\hline commitment_ncs & Safety_culture_ncs &, 653 &, 046 & 14,066 \\
\hline behaviour_ncs & Safety_culture_ncs &, 537 &, 046 & 11,718 \\
\hline awareness_ncs & Safety_culture_ncs &, 552 &, 041 & 13,595 \\
\hline adaptation_ncs & Safety_culture_ncs &, 613 &, 043 & 14,141 \\
\hline information_ncs & Safety_culture_ncs &, 602 &, 039 & 15,248 \\
\hline justness_ncs & Safety_culture_ncs &, 746 &, 057 & 13,047 \\
\hline
\end{tabular}

Regarding model fit values are acceptable and have been calculated as below:

Table 16: Regarding model fit values

\begin{tabular}{|l|l|l|l|l|l|}
\hline CMIN Model & NPAR & CMIN & DF & P & CMIN/DF \\
\hline Default model & 13 & 17,650 & 8 &, 024 & 2,206 \\
\hline Saturated model & 21 &, 000 & 0 & & \\
\hline Independence model & 6 & 856,479 & 15 &, 000 & PGFI \\
\hline $\begin{array}{l}\text { RMR, GFI } \\
\text { Model }\end{array}$ & RMR & GFI & AGFI &, 371 & \\
\hline Default model &, 015 &, 974 &, 932 & & \\
\hline $\begin{array}{l}\text { Saturated model } \\
\text { Independence model }\end{array}$ &, 000 & 1,000 & &, 235 & \\
\hline $\begin{array}{l}\text { RMSEA } \\
\text { Model }\end{array}$ & RMSEA & LO 90 & HI 90 & PCLOSE & \\
& & & & & \\
\hline
\end{tabular}




\begin{tabular}{|l|l|l|l|l|l|}
\hline Default model &, 074 &, 026 &, 121 &, 171 & \\
\hline Independence model &, 506 &, 478 &, 535 &, 000 & CFI \\
\hline $\begin{array}{l}\text { Baseline Comparisons } \\
\text { Model }\end{array}$ & $\begin{array}{l}\text { NFI } \\
\text { Delta1 }\end{array}$ & $\begin{array}{l}\text { RFI } \\
\text { rho1 }\end{array}$ & $\begin{array}{l}\text { IFI Delta2 } \\
\text { rho2 }\end{array}$ & TLI &, 989 \\
\hline Default model &, 979 &, 961 &, 989 &, 978 & 1,000 \\
\hline Saturated model & 1,000 &, 000 &, 000 &, 000 &, 000 \\
\hline
\end{tabular}

\subsubsection{MECHANICS ECAST MODEL PATH ANALYSIS}

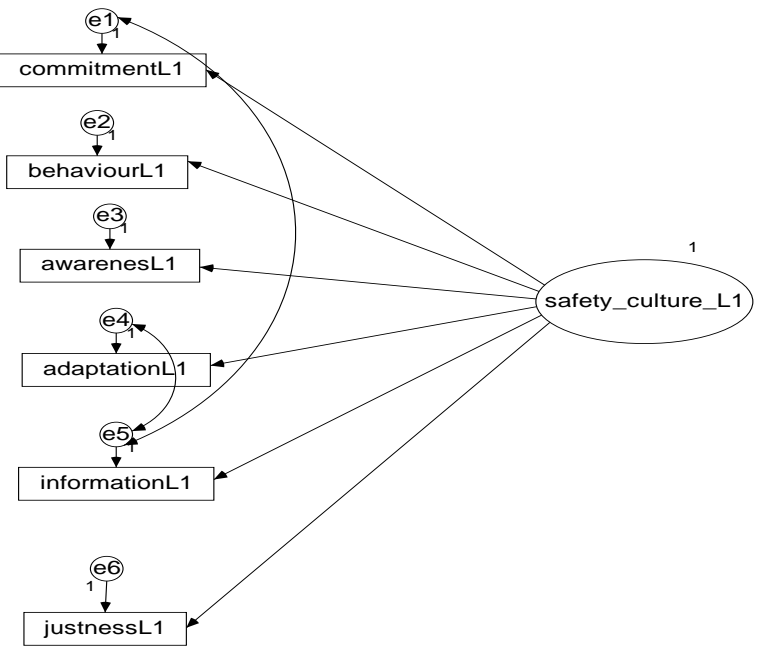

Figure 13: Mechanics ECAST Model Path Analysis

The concerned SEM 2 regression weights and estimated values are acceptable levels and seen as follow Regression Weights: (Group number 1 - Default model)

Table 17: Regression Weights: (Group number 1 - Default model)

\begin{tabular}{|l|l|l|l|l|l|}
\hline & & Estimate & S.E. & C.R. & P \\
\hline commitmentL1 & safety_culture_L1 &, 672 &, 072 & 9,334 & $* * *$ \\
\hline behaviorL1 & safety_culture_L1 &, 548 &, 058 & 9,530 & $* * *$ \\
\hline awarenessL1 & safety_culture_L1 &, 570 &, 064 & 8,950 & $* * *$ \\
\hline
\end{tabular}




\begin{tabular}{|l|l|l|l|l|l|}
\hline adaptabilityL1 & safety_culture_L1 &, 557 &, 068 & 8,149 & $* * *$ \\
\hline informationL1 & safety_culture_L1 &, 611 &, 062 & 9,842 & $* * *$ \\
\hline justnessL1 & safety_culture_L1 &, 729 &, 096 & 7,582 & $* * *$ \\
\hline
\end{tabular}

Regarding model fit values are acceptable and have been calculated as below:

Table 18: Regarding model fit values

\begin{tabular}{|c|c|c|c|c|c|}
\hline CMIN Model & NPAR & CMIN & $\mathrm{DF}$ & $\mathrm{P}$ & CMIN/DF \\
\hline Default model & 14 & 5,277 & 7 & 626 &, 754 \\
\hline Saturated model & 21 & 000 & 0 & & \\
\hline Independence model & 6 & 357,857 & 15 & 000 & 23,857 \\
\hline $\begin{array}{l}\text { RMR, GFI } \\
\text { Model }\end{array}$ & RMR & GFI & AGFI & PGFI & \\
\hline Default model &, 013 & ,980 & ,941 & ,327 & \\
\hline Saturated model &, 000 & 1,000 & & & \\
\hline Independence model &, 320 &, 329 &, 061 & ,235 & \\
\hline $\begin{array}{l}\text { RMSEA } \\
\text { Model }\end{array}$ & RMSEA & LO 90 & HI 90 & PCLOSE & \\
\hline Default model &, 000 &, 000 &, 108 &, 750 & \\
\hline Independence model &, 501 &, 457 &, 547 & 000 & \\
\hline $\begin{array}{l}\text { Baseline Comparisons } \\
\text { Model }\end{array}$ & $\begin{array}{l}\text { NFI } \\
\text { Delta1 }\end{array}$ & $\begin{array}{l}\text { RFI } \\
\text { rho1 }\end{array}$ & $\begin{array}{l}\text { IFI } \\
\text { Delta2 }\end{array}$ & $\begin{array}{l}\text { TLI } \\
\text { rho2 }\end{array}$ & CFI \\
\hline Default model & ,985 & ,968 & 1,005 & 1,011 & 1,000 \\
\hline Saturated model & 1,000 & & 1,000 & & 1,000 \\
\hline Independence model &, 000 &, 000 &, 000 & ,000 &, 000 \\
\hline
\end{tabular}

\section{CONCLUSIONS \& RECOMMENDATIONS}

According to the results of the exploratory factor and reliability analysis for each dimension, it was determined that the Certifying Staff's factor loading values are ranging from 0.61 to 0.88 which are acceptable. At the end of the factor and reliability analysis, either the related KMO or Barlett or Cronn Bach's Alpha values which are acceptable and indicated in table 19 and 20 for each group. 
Table 19: KMO and Barlett values for each dimesion

\begin{tabular}{|l|l|l|l|l|l|l|l|}
\hline Group & Dimensions & Commitment & Behaviour & Awareness & Adaptation & Information & Justness \\
\hline \multirow{2}{*}{ CS } & KMO & 0,81 & 0,68 & 0,59 & 0,72 & 0,84 & 0,78 \\
\cline { 2 - 9 } & Barlett & 0,00 & 0,00 & 0,00 & 0,00 & 0,00 & 0,00 \\
\hline \multirow{2}{*}{ Nechanics } & KMO & 0,88 & 0,74 & 0,73 & 0,79 & 0,83 & 0,84 \\
\cline { 2 - 9 } & Barlett & 0,00 & 0,00 & 0,00 & 0,00 & 0,00 & 0,00 \\
\hline & KMO & 0,90 & 0,80 & 0,76 & 0,79 & 0,90 & 0,79 \\
\cline { 2 - 9 } & Barlett & 0,00 & 0,00 & 0,00 & 0,00 & 0,00 & 0,00 \\
\hline
\end{tabular}

Table 20: Cron Bach's Alpha values for each dimension

\begin{tabular}{|l|l|l|l|l|l|l|l|}
\hline Group & Dimensions & Commitment & Behaviour & $\begin{array}{l}\text { Awarenes } \\
\text { s }\end{array}$ & Adaptation & Information & Justness \\
\hline CS & $\begin{array}{l}\text { CronnBach's } \\
\text { Alpha }\end{array}$ & 0,81 & 0,74 & 0,68 & 0,70 & 0,86 & 0,74 \\
\hline Mechanics & $\begin{array}{l}\text { CronnBach's } \\
\text { Alpha }\end{array}$ & 0,90 & 0,71 & 0,80 & 0,77 & 0,91 & 0,76 \\
\hline Non-CS & $\begin{array}{l}\text { CronnBach's } \\
\text { Alpha }\end{array}$ & 0,86 & 0,76 & 0,77 & 0,77 & 0,91 & 0,86 \\
\hline
\end{tabular}

The relevant overall model fit summary values are indicated as seen below:

Table 21: Model fit indices for each group

\begin{tabular}{|l|l|l|l|l|l|l|l|}
\hline Group & $\begin{array}{l}\text { CMIN/DIF } \\
<\mathbf{5}\end{array}$ & $\begin{array}{l}\text { GFI } \\
\mathbf{> 0 , 8 5}\end{array}$ & $\begin{array}{l}\text { AGFI } \\
\mathbf{> 0 , 8 0}\end{array}$ & $\begin{array}{l}\text { CFI } \\
\mathbf{> 0 , 9 0}\end{array}$ & $\begin{array}{l}\text { NFI } \\
\mathbf{> 0 , 9 0}\end{array}$ & $\begin{array}{l}\text { TLI } \\
\mathbf{8 0 , 9 0}\end{array}$ & $\begin{array}{l}\text { RMSEA } \\
<\mathbf{0 , 0 8}\end{array}$ \\
\hline $\begin{array}{l}\text { Safety Culture } \\
\text { Certifying Staff }\end{array}$ & 0,422 & 0,988 & 0,971 & 1,000 & 0,980 & 1,029 & 0,00 \\
\cline { 2 - 8 } Safety Culture \\
\begin{tabular}{l} 
Mechanics \\
\cline { 2 - 8 }
\end{tabular} & 0,754 & 0,980 & 0,941 & 1,000 & 0,985 & 1,015 & 0,000 \\
$\begin{array}{l}\text { Safety Culture Non- } \\
\text { Certifying Staff }\end{array}$ & 2,206 & 0,974 & 0,932 & 0,989 & 0,979 & 0,978 & 0,074 \\
\hline
\end{tabular}

When examined model fit indices of each group, the values of CMIN/DIF, the values of GFI, the values of AGFI the values of CFI, the values of NFI, the values of TLI and the values of RMSEA were found acceptable. As a result, above mentioned summary tables shows that this structural equation model is acceptable since obtained data, values and goodness of fitness indices are statistically satisfactory levels (Joreskog ve Sorborm, 1993: Kline 1998). Each group's RMSEA value is lower than 0.08. Thereby, model estimation results and model god of fitness values such as CMIN/DEF, RMSEA, TLI, NFI, AGFI are satisfactory to explain the model.

To conclude with that, Westrum's safety culture measurement model can use in maintenance repair organizations. There are more than 500 maintenance repair organizations which may benefit from this model in the EU and Turkey. Finally, this study is addressing safety culture measurement model fitness in the maintenance repair organizations not the others aviation operations therefore it must be validated before using others type of aviation operations. 


\section{REFERENCES}

[1] Reason, James, and Alan Hobbs. Managing Maintenance Error. Chp. 11. 2003. 145-148.

[2] Piers, Montijn \& Balk. Safety Culture Frame Work for the ECAST-WG. NLR, 2009.

[3] Hudson, Patrick. Safety Management and Safety Culture: The Long, Hard and Winding Road. Leiden University, 2007.

[4] IAEA. Workshop on Global Safety Culture: National Factors Relevant to Safety Culture, Vienna, 2014.

[5] Gerede, Ender. SMS Workshop, Anatolian University, 2012.

[6] Reason, J. T. A Life in Error: From Little Slips to Big Disasters, 2013. 81.

[7] Wiegmann, A. Douglas. Development and Initial Validation of a Safety Culture Survey for Commercial Aviation. Savoy, Ill.: University of Illinois at Urbana-Champaign, Aviation Human Factors Division, 2003.

[8] Westrum, Ron. Culture with requisite imagination. In J. A. Wise, V. D. Hopkin, \& P. Stager, Verification and Validation of Complex Systems: Human Factors Issues. NATO ASI Series F, Vol.110. Berlin: Springer-Verlag, pp. 315-332. 1993.

[9] Parker, Dianne, Lawrie, Matthew \& Hudson, Patrick. A framework for understanding the development of organizational safety culture. Safety science, 44. 2006.

[10] Fleming, Mark. Offshore Technology Report. Safety Culture Maturity Model, 49. Sudbury: HSE Books, 1999.

[11] HSG 48. In Reducing Error and Influencing Behaviour. 2nd ed. Sudbury: HSE Books, 1999.

[12] Saunders, Mark, and Lewis, Philip. Research Methods for Business Students. 2nd ed. Harlow, England: Prentice Hall, 2000.

[13] Nunnally, C. Jum. Psychometric Theory. 3rd ed. New York: McGraw-Hill, 1994.

[14] Rencher, C. Alvin and William F. Christensen. Methods of Multivariate Analysis. Third ed. Hoboken, New Jersey: Wiley, 2012.

[15] Rencher, C. Alvin and William F. Christensen. Methods of Multivariate Analysis. 1st ed. Hoboken, New Jersey: Wiley, 1998.

[16] Hair, Joseph F. Multivariate Data Analysis. 5th ed. Upper Saddle River, N.J.: Prentice Hall, 1998.

[17] Tavşancıl, Ezel. Tutumların Ölçülmesi ve SPSS ile Veri Analizi. 2nd ed. Ankara:Nobel Yayınlart, 2005.

[18] Tabachnick, Barbara G., and Linda S. Fidell. Using Multivariate Statistics. 4th ed. Boston: Pearson/Allyn \& Bacon, 2001.

[19] Schumacker, Randall E., and Richard G. Lomax. A Beginner's Guide to Structural Equation Modelling. 1st ed. Mahwah, N.J.: Lawrence Erlbaum Associates, 1996.

[20] Kline, Paul. The Handbook of Psychological Testing. 2nd ed. London: Routledge, 1998.

[21] Vandenberg \& Scarpello. The matching model: An examination of the processes underlying realistic job previews. Journal of Applied Psychology, 75(1), 52-67. doi:10.1037/0021-9010.75.1.52. 1990.

[22] Hooper, Daire, Coughlan, Joseph \& Mullen, Michael. Structural Equation Modelling: Guidelines for Determining Model Fit. Electronic Journal of Business Research Methods, 6(1), 53-59, 2008. 
[23] Hu \& Bentler. Cut off criteria for fit indexes in covariance structure analysis: Conventional criteria versus new alternatives. Structural Equation Modelling, 6(1), 155. doi:10.1080/10705519909540118. 1999.

[24] Kelloway, E. Kevin. Using LISREL for Structural Equation Modelling: A researcher's Guide. Thousand Oaks: Sage Publications, 1989.

[25] Sümer, Nebi. Yapısal Eşitlik Modelleri. Türk Psikoloji Yazıları, 3 (6), 49-74, 2000.

[26] Evans, B., Glendon, A. I., \& Creed, P. A. Development and initial validation of an aviation safety climate scale. Journal of Safety Research, 38, 675-682, 2007.

[27] Jöreskog, G. Karl \& Sörbom, Dag. LISREL 8: Structural Equation Modelling with the SIMPLIS Command Language. Chicago: Scientific Software International, Inc, 1993.

[28] Şimşek, G. Gülhayat. Latent Değişkenli Yapısal Denklem Modellerine İlişkin Bir Uygulama, Doctorate Thesis, Marmara University, 2007. 